\title{
STRATEGI KOPING ANAK YANG MEMILIKI PENGALAMAN KEHILANGAN ORANG TUA DI LKSA NUGRAHA KOTA BANDUNG
}

\author{
Denny Maulana Pratama \\ Politeknik Kesejahteraan Sosial Bandung, denny.peksos@gmail.com
}

\begin{abstract}
This article aims to describe children's coping strategies for responding to the experience of losing a parent. It begins with a description of the characteristics of the child, the background of the loss of a parent, problem-focused coping, and emotion-focused coping in children. This study uses a qualitative research approach with descriptive methods. Informants in this study included 6 children and 2 caregivers. Data collection techniques used in this study were in-depth interviews and documentation studies. Checking the validity of the data is also done through triangulation of sources and time. Data analysis techniques were carried out by means of data reduction, data presentation, and drawing conclusions. The findings show that children have coping strategies for responding to the experience of losing their parents through problem-focused coping and emotion-focused coping, but there are still issues with problem-focused coping, such as children not taking the initiative to express problems to caregivers and a lack of media for group meetings in the disclosure of the problem of losing a parent. In addition, there are also several problems with emotion-focused coping, including the child's unwillingness to express the emotions he feels, the rejection of the loss of a parent that is still felt, and the feelings of inferiority that the child still has. Based on the results of this study, the researchers recommend that treatment through group media can contribute to improving children's coping abilities.
\end{abstract}

\section{Keywords:}

coping strategy, problem-focused coping, emotion-focused coping, experience of losing parents

\begin{abstract}
Abstrak
Artikel ini bertujuan untuk mendeskripsikan strategi koping anak dalam merespon pengalaman kehilangan orang tua. Hal tersebut diawali dengan penjabaran mengenai karakteristik anak, latar belakang kehilangan orang tua, strategi berpusat pada masalah serta strategi berpusat pada emosi pada anak. Penelitian ini menggunakan pendekatan penelitian kualitatif dengan metode deskriptif. Informan dalam penelitian ini meliputi 6 orang anak dan 2 orang pengasuh. Teknik pengumpulan data yang digunakan dalam penelitian ini adalah wawancara mendalam dan studi dokumentasi. Pemeriksaan keabsahan data juga dilakukan melalui triangulasi sumber dan waktu. Teknik analisis data dilakukan dengan cara reduksi data, penyajian data, dan penarikan kesimpulan. Hasil penelitian menunjukkan anak memiliki strategi koping dalam merespon pengalaman kehilangan orang tua melalui strategi berpusat pada masalah dan strategi berpusat pada emosi, namun masih terdapat permasalahan pada strategi berpusat pada masalah, yakni anak belum memiliki inisiatif dalam mengungkapkan permasalahan kepada pengasuh dan belum tersedianya media pertemuan kelompok dalam pengungkapan permasalahan kehilangan orang tua. Selain itu, terdapat juga beberapa permasalahan pada strategi berpusat pada emosi, meliputi ketidakinginan anak dalam mengungkapkan emosi yang dirasakannya, penolakan kehilangan orang tua yang masih dirasakan, serta perasaan rendah diri yang masih dimiliki oleh anak. Berdasarkan hasil penelitian tersebut, peneliti merekomendasikan bahwa treatment melalui media kelompok dapat berkontribusi dalam meningkatkan kemampuan koping pada anak.
\end{abstract}

\section{Kata Kunci:}

strategi koping, strategi berpusat pada masalah, strategi berpusat pada emosi, pengalaman kehilangan orang tua 


\section{PENDAHULUAN}

Manusia merupakan makhluk sosial yang saling berinteraksi satu sama lain sehingga membentuk satu kesatuan. Kesatuan tersebut dimulai dari unit sosial terkecil dari masyarakat yakni keluarga. Umumnya keluarga beranggotakan ayah, ibu, dan anak, namun dalam perkembangan waktu keluarga dapat memiliki cakupan anggota yang lebih luas. Anggota keluarga dalam cakupan yang lebih luas dapat terdiri dari nenek, kakek, maupun saudara lainnya. Zastrow (2015) juga mengatakan bahwa keluarga memiliki beberapa jumlah anggota yang dapat digolongkan pada kategori keluarga inti maupun keluarga besar.

Keluarga inti dan keluarga besar memiliki fungsi yang sama yakni menjadi tempat pertama manusia melakukan proses komunikasi dan menjalin relasi sebagai wujud sosialisasi. Proses tersebut dilakukan anggota keluarga sesuai dengan perannya masingmasing baik sebagai anak maupun orang tua. Pelaksanaan peran bertujuan untuk menjaga keluarga agar terhindar dari permasalahan yang dapat mengancam keutuhan keluarga. Apabila terhindar dari permasalahan, maka hubungan yang terjalin di dalam keluarga juga berjalan harmonis.

Keharmonisan hubungan keluarga yang paling mendasar ditentukan oleh kelengkapan anggota. Layaknya sebuah sistem, jika subsistem mengalami gangguan baik karena kerusakan ataupun mati maka berpotensi mengalami hambatan. Begitu pula dengan keluarga yang dapat mengalami hambatan karena pelaksanaan peran anggotanya terganggu. Dampaknya keluarga berada dalam kondisi yang tidak harmonis. Oleh karena itu peran orang tua dan anak menjadi sangat penting dalam menciptakan keharmonisan keluarga.
Peran yang dimaksud berkaitan dengan kemampuan orang tua dalam memenuhi kebutuhan dasar serta memberikan pengasuhan terbaik bagi anak disetiap fase-fase kehidupan. Pentingnya peran orang tua juga dikemukakan oleh Sri Hardyanti et al., (2017) yang menyatakan bahwa peran ayah dan ibu berpengaruh pada kualitas perkembangan anak. Apabila peran dapat ditampilkan dengan baik, maka hambatan dalam masa perkembangan anak juga dapat dihindari selaras dengan kehadiran orang tua di dalam kehidupan anak.

Keberhasilan dalam menampilkan peran di keluarga juga ditentukan oleh jumlah anggotanya. Apabila jumlahnya lengkap, maka peran keluarga dapat ditampilkan secara optimal. Selain itu, kesejahteraan keluarga juga dipengaruhi oleh jumlah keluarga. Keterkaitan jumlah keluarga dan hubungannya dengan peran juga sesuai dengan pendapat (Telaumbanua \& Nugraheni, 2018) yang mengemukakan bahwa kesejahteraan keluarga berkaitan dengan pendapatan serta struktur anggotanya.

Keluarga yang tidak dapat memenuhi kebutuhan ekonominya secara wajar karena kematian orang tua akan mengalami hambatan dalam melaksanakan kehidupan. Hambatan tersebut berkaitan dengan penentuan masa depan anak baik dari segi tempat tinggal, pendidikan, maupun hal-hal yang dapat mempengaruhi anak secara kognisi, emosi, maupun perilakunya pasca kehilangan orang tuanya.

Fakta yang berbeda ditunjukkan di lapangan terkait dengan keberadaan orang tua dalam mendampingi anaknya. Salah satunya disebabkan karena orang tua anak telah meninggal dunia. Pada kondisi 
tersebut berbagai kemungkinan dapat terjadi khususnya berkaitan dengan tempat tinggal anak. Anak dapat tinggal dengan salah satu orang tuanya yang masih hidup, tinggal dengan saudaranya, atau tinggal di lembaga kesejahteraan sosial anak. Alternatif kemungkinan tinggalnya anak ditentukan pula dengan dukungan yang diperoleh baik dari keluarga inti maupun keluarga besar.

Pengalaman kehilangan orang tua yang dialami oleh anak menunjukkan perbedaan kondisi. Terlebih lagi ketika anak tidak tinggal bersama dengan keluarga namun dirujuk ke lembaga kesejahteraan sosial anak. Tinggalnya anak di lembaga kesejahteraan sosial anak pasca meninggalnya orang tua menjadi tantangan tersendiri karena tidak adanya pendampingan dari keluarga secara langsung. Pendampingan hanya dilakukan oleh pihak lembaga baik yang dikelola oleh swasta maupun pemerintah.

Data dari Kementerian Sosial (2019) bahwa Indonesia memiliki 4.327 LKSA yang terdaftar resmi dan setiap tahun menyelenggarakan rakernas Forum LKSAPSAA. Salah satu provinsi yang memiliki jumlah LKSA paling banyak di Indonesia adalah Jawa Barat yakni sejumlah 835 LKSA. Kota Bandung juga menjadi kota yang memiliki LKS yang berfokus pada anak sehingga memiliki 53 LKSA. Berbagai lembaga kesejahteraan sosial anak terdapat di beberapa wilayah Indonesia tak terkecuali lembaga Kesejahteraan Sosial Anak (LKSA) Nugraha yang terletak di Kota Bandung.

LKSA Nugraha merupakan salah satu lembaga yang memiliki akreditasi A dalam memberikan pelayanan sosial bagi anak. Anak asuh yang berada dalam lembaga ini dapat digolongkan sebagai anak yatim piatu (ayah dan ibunya telah meninggal dunia) atau anak yang berasal dari keluarga yang mengalami permasalahan ekonomi. Perujukannya juga dapat melalui keluarga maupun masyarakat serta menerima anak laki-laki dan perempuan. Terbatasnya jumlah asrama membuat anak asuh juga dapat tinggal di luar asrama bersama keluarganya yang berada di wilayah Kota Bandung.

Keberadaaan anak asuh baik yang tinggal di asrama maupun di luar asrama dilandasi pada Standar Nasional Pengasuhan Anak (SNPA) yang memposisikan LKSA sebagai gate keeper antara anak dengan keluarga. Petr (2004) juga mengemukakan bahwa terdapat prinsip least-restrictive alternative dan continum of care yang mendukung anak tetap dalam asuhan keluarga. Selain itu opsi dalam pengasuhan anak dapat dilakukan oleh keluarga inti, keluarga besar, kerabat, keluarga angkat, dan terakhir panti asuhan. Alternatif tersebut dapat dilakukan ketika dalam kondisi tertentu misalnya kematian orang tua seperti yang terjadi di LKSA Nugraha Kota Bandung.

Sesuai kondisi di asrama terdapat anak-anak yang memiliki pengalaman kehilangan orang tua baik karena kematian ayah, ibu, maupun keduanya. Kondisi tersebut mengakibatkan anak mengalami gangguan karena pengalaman kehilangan yang dialami. Berbagai gangguan dapat terjadi pada anak selaras dengan latar belakang kehilangan orang tua yang dialami serta situasi menekan yang dapat terjadi ketika berada di asrama.

Anak asuh memiliki latar belakang kehilangan orang tua yang berbeda serta mengganggu mereka ketika melaksanakan aktivitas di asrama. Terhambatnya aktivitas yang dilakukan anak berkaitan dengan pengalaman kehilangan orang tua yang dialami. (Salscheider, 2016) 
mengemukakan bahwa pengalaman kehilangan orang tua dapat menggangu anak sepanjang hidupnya selaras dengan perubahan yang terjadi dalam diri anak. Perubahan yang terjadi dapat mempengaruhi anak secara mental dan perilaku.

Kondisi kehidupan yang baru tanpa adanya orang tua juga mengakibatkan anak mengalami gangguan dalam mengelola emosi. Setiap anak memiliki pengalaman yang melibatkan emosi semasa hidup bersama dengan orang tuanya. Ketika anak tidak dapat merasakan lagi pengalaman itu, maka respon secara emosional didominasi oleh perasaan kehilangan. Pernyataan tersebut selaras dengan yang dikemukakan oleh McGuire et al., (2013) bahwa pengalaman kehilangan orang tua mengakibatkan anak memiliki perasaan kesedihan seperti marah, cemas, agresif, serta menyalahkan diri sendiri. Apabila hal tersebut dibiarkan begitu saja maka anak dapat mengalami gangguan karena pengalaman kehilangan orang tua yang dialami.

Potensi gangguan karena pengalaman kehilangan orang tua semakin dirasakan ketika anak tinggal di asrama. Berbagai latar belakang perujukan tidak selalu menjadi inisiatif anak sehingga perasaan berduka akibat kehilangan orang tua juga dapat mengganggu kehidupan anak di asrama. Schofield et al., (2011) mengemukakan bahwa terpisahnya anak dan keluarga karena tinggal di panti asuhan dapat menimbulkan perasaan kehilangan orang tua yang sudah meninggal dalam jangka panjang. Perasaan tersebut muncul dikarenakan anak tidak merasakan dukungan keluarga secara langsung.

Emosi anak yang kehilangan orang tua juga ditunjukkan melalui perilaku. Perilaku yang dimunculkan oleh anak dapat berupa penarikan diri dari lingkungan sosial atau bentuk perilaku yang menunjukkan rasa putus asa. Wong (2013) mengemukakan bahwa anak yang memiliki pengalaman kehilangan orang tua cenderung merasakan penolakan atas kematian orang tua yang telah terjadi. Penolakan itu dapat ditunjukkan oleh anak ataupun tidak, hal itu dikarenakan perasaan malu dan takut. Oleh karena itu, perlu adanya dukungan bagi anak dalam membantu mengungkapkan emosi yang dirasakan.

Selain gangguan yang berkaitan dengan pengungkapan emosi, anak yang memiliki pengalaman kehilangan orang tua juga dihadapkan pada permasalahan untuk memecahkan masalah. Pemecahan masalah berkaitan dengan kemampuan anak dalam memahami pengalaman kehilangan orang tua, mencari pihak yang dapat membantunya memecahkan masalahnya, serta merencanakan solusi penyelesaian permasalahan kehilangan orang tua di asrama. Leming \& Dickinson (2011) mengemukakan bahwa kemampuan memahami pengalaman kehilangan orang tua dapat diperoleh dari hasil konstruksi pemikiran yang dilakukan oleh anak dari lingkungan sosial dimana anak tumbuh dan berkembang. Dengan kata lain lingkungan asrama memiliki pengaruh terhadap penyelesaian permasalahan kehilangan orang tua ketika berada di asrama.

Beberapa kondisi di atas menunjukkan pengalaman kehilangan orang tua merupakan gangguan yang dapat dirasakan anak ketika berada di asrama. Gangguan tersebut dapat terjadi baik pada tataran fisik, emosi, maupun kognisi. Mitchell \& Murillo (2016) mengemukakan bahwa pengalaman kehilangan orang tua merupakan pengalaman traumatis yang mempengaruhi emosi dan kognisi sehingga 
kemampuan dalam mengelola emosi dan memecahkan masalah menjadi hal yang penting bagi anak. Tujuannya adalah agar anak dapat menyikapi pengalaman kehilangan tersebut melalui perilaku positif yang tidak merugikan diri sendiri.

Berdasarkan hasil penelitian di lapangan dan landasan teori yang mendukung, artikel ini bertujuan untuk menggambarkan dan menganalisis strategi koping pada anak yang memiliki pengalaman kehilangan orang tua di LKSA Nugraha Kota Bandung.

\section{METODE}

Penelitian ini menggunakan metode kualitatif dengan pendekatan deskriptif. Data yang dihasilkan dari penggunaan metode ini berupa kalimat tertulis atau verbal dari informan yang telah ditetapkan sesuai dengan fokus penelitian yakni anak yang memiliki pengalaman kehilangan orang tua serta pengasuh sebagai informan pendukung. Metode penelitian kualitatif dipilih untuk memperoleh data yang mendalam serta memiliki makna tertentu sehingga dapat dianalisis dengan pendekatan deskriptif (Creswell, 2014).

Pendekatan deskriptif bertujuan untuk membuat deskripsi mengenai fakta-fakta yang ditemukan serta hubungan antar fenomena yang diteliti dalam penelitian. Fakta dan fenomena tersebut berkaitan dengan strategi koping anak yang memiliki pengalaman kehilangan orang tua, hal tersebut selaras dengan tujuan penelitian ini yang menggambarkan penggunaan strategi koping serta hubungannya dengan pengalaman kehilangan orang tua ketika anak berada di lembaga kesejahteraan sosial anak.

Data pada penelitian ini diperoleh melalui kegiatan wawancara mendalam dan studi dokumentasi dengan 6 orang anak asuh yang terdiri dari 4 orang anak perempuan dan
2 orang anak laki-laki. Jumlah anak ditentukan menggunakan teknik purposive sampling. Penggunaan teknik tersebut selaras dengan tujuan peneliti yang berfokus pada anak yang memiliki pengalaman kehilangan orang tua saja. Selain itu peneliti juga melakukan kegiatan wawancara bersama dengan 2 orang pengasuh yang memiliki kewenangan dalam mengasuh anak selama di LKSA Nugraha.

Pada penelitian ini penelit
melakukan analisis data dengan mengelompokkan data kedalam suatu kategori sehingga dapat ditemukan tematema hasil penelitian, dalam hal ini penelitian yang berkaitan dengan strategi koping anak yang memiliki pengalaman kehilangan orang tua di LKSA Nugraha Kota Bandung. Analisis data dilakukan selaras dengan pendapat yang dikemukakan oleh Miles, Huberman, \& Saldana (2014) yang mengemukakan bahwa analisis data dilakukan melalui tahapan reduksi data, penyajian data, dan penarikan kesimpulan.

\section{HASIL PENELITIAN}

Hasil penelitian diperoleh selaras dengan tujuan yang telah ditetapkan

peneliti yakni untuk mendeskripsikan karakteristik anak, latar belakang kehilangan orang tua anak, serta strategi koping anak yang meliputi strategi berpusat pada masalah dan strategi berpusat pada emosi pada anak di Lembaga Kesejahteraan Sosial Anak (LKSA) Nugraha Kota Bandung. Aspek strategi berpusat pada masalah disesuaikan dengan sub-aspek yang ada didalamnya yakni upaya anak dalam mencari dukungan orang lain, upaya konfrontasi yang dilakukan anak, serta upaya anak dalam menentukan solusi atas 
permasalahan kehilangan orang tua yang dialaminya.

Aspek strategi berpusat pada emosi juga disesuaikan dengan sub-aspek yang ada didalamnya yakni upaya pengabaian anak, upaya kontrol diri anak, upaya penerimaan tanggung jawab anak, upaya penghindaran diri anak, serta upaya pemaknaan anak atas pengalaman kehilangan orang tua yang dialami. Adapun hasil penelitian dapat dijabarkan sebagai berikut:

\section{Karakteristik Anak}

Hasil penelitian mengenai karakteristik anak dapat digambarkan melalui tabel berikut ini:

Tabel 1. Karakteristik Anak

\begin{tabular}{|l|l|r|r|r|}
\hline No & Nama & $\begin{array}{c}\text { Jenis } \\
\text { Kelamin }\end{array}$ & $\begin{array}{c}\text { Usia } \\
\text { (Tahun) }\end{array}$ & Status \\
\hline 1 & SA & Laki-laki & 16 & Yatim \\
\hline 2 & SI & Perempuan & 17 & $\begin{array}{r}\text { Yatim } \\
\text { Piatu }\end{array}$ \\
\hline 3 & AL & Perempuan & 18 & $\begin{array}{r}\text { Yatim } \\
\text { Piatu }\end{array}$ \\
\hline 4 & NI & Perempuan & 16 & Yatim \\
\hline 5 & CA & Laki-laki & 17 & Piatu \\
\hline 6 & FN & Laki-laki & 16 & $\begin{array}{r}\text { Yatim } \\
\text { Piatu }\end{array}$ \\
\hline
\end{tabular}

Tabel 1. Menunjukan bahwa terdapat 6 orang anak yang memiliki pengalaman kehilangan orang tua yang meliputi 4 orang

perempuan dan 2 orang laki-laki. Usia anakanak tersebut berada pada rentang 16-18 tahun. Anak tersebut juga memiliki status kehilangan orang tua yang berbeda yakni 3 orang anak yatim piatu, 2 orang anak yatim, dan 1 orang anak piatu. Istilah yatim dalam penelitian ini adalah anak yang kehilangan ayah sedangkan istilah piatu disematkan pada anak yang kehilangan ibu. Penjelasan mengenai karakteristik anak diuraikan sebagai berikut:

a. Informan SA
Informan SA merupakan anak kelima dari pasangan HI dan WI yang lahir di Kota Garut. SA berusia 16 tahun dan sedang menempuh pendidikan di kelas 10 sekolah menengah akhir. SA menempuh pendidikan di sekolah yang berada dalam naungan Yayasan Esa Nugraha. Setiap hari SA bersekolah dari hari Senin hingga Sabtu layaknya sekolah reguler pada umumnya. Setelah kegiatan sekolah SA kembali ke asrama dimana tempat SA tinggal seharihari.

Sebagai seorang perempuan, SA tinggal bersama dengan teman-teman perempuan lainnya di asrama putri dan tidak tinggal di luar asrama. Yayasan Esa Nugraha memiliki ketentuan anak asuh yang tinggal di dalam dan di luar asrama namun ketika ada kegiatan semua anak asuh dihimbau untuk mengikuti kegiatan tak terkecuali SA. Selain kegiatan di asrama SA juga mengikuti kegiatan di sekolah dan terdaftar sebagai anggota ekstrakurikuler Rohani Islam. Selama tinggal di asrama, SA melakukan kegiatan rutin baik yang dilakukan di asrama maupun di sekolah.

SA sudah tinggal di asrama selama 7 bulan. Keluarganya yang merujuk SA ke asrama bersamaan dengan tetangga dekatnya yang satu desa dengannya setelah

ayah SA meninggal dunia. Ketika dirujuk ke asrama, keluarganya juga ikut mengantar dan telah memenuhi persyaratan tinggal di asrama. Setelah tinggal di asrama ia tempatkan ke asrama putri yang telah ditetapkan oleh pengurus yayasan Esa Nugraha.

b. Informan SI

Informan SI merupakan anak ketiga dari pasangan $\mathrm{AE}$ dan $\mathrm{HH}$ yang lahir di Kabupaten Bandung. SI berusia 17 tahun dan sedang menempuh pendidikan di kelas 
11 Sekolah Menengah Akhir yang berada dalam naungan Yayasan Esa Nugraha. Setiap hari SI bersekolah dari hari Senin hingga Sabtu layaknya sekolah reguler pada umumnya. Setelah mengikuti kegiatan sekolah, SI kembali ke asrama untuk mengikuti kegiatan di asrama.

SI tinggal di asrama putri bersama dengan teman-teman lainnya. Berbagai kegiatan diikuti oleh SI di asrama. Selain kegiatan di asrama SI juga mengikuti kegiatan di sekolah dan terdaftar sebagai anggota ekstrakurikuler Rohani Islam. Selama tinggal di asrama, SI melakukan kegiatan rutin baik yang dilakukan di asrama maupun di sekolah.

SI tinggal di asrama sudah berjalan dua tahun semenjak kelas 2 SMP. Perujukan SI ke asrama dilakukan oleh keluarganya atas dasar pencarian informasi SI ke teman sekolahnya yang tinggal di asrama terkait persyaratan menjadi anak asuh. Setelah menyampaikan kepada kakaknya SI akhirnya dirujuk ke asrama. Kakaknya menjadi wali perujukan karena ayah dan ibu SI sudah meninggal dunia.

\section{c. Informan AL}

Informan AL merupakan anak kedua dari pasangan AD dan NI. Saat ini AL yang lahir di Kota Cianjur. AL berusia 18 tahun dan sedang menempuh pendidikan di kelas 12 sekolah menengah atas yang berada dalam naungan Yayasan Esa Nugraha. AL menjalankan kegiatan rutin pendidikan dengan bersekolah setiap hari Senin hingga Sabtu layaknya sekolah reguler pada umumnya. Setelah mengikuti kegiatan sekolah, AL kembali ke asrama untuk mengikuti kegiatan di asrama seperti teman-temannya yang lain.

Sebelum tinggal di asrama AL tinggal di Cianjur bersama dengan paman dan bibinya yang merupakan saudara dari ayahnya. Tinggalnya Al dengan paman dan bibinya dikarenakan ayah dan ibunya telah meninggal dunia. AL juga tidak tinggal bersama dengan kakaknya, karena DI sebagai kakak tinggal bersama dengan paman dan bibi dari keluarga ibunya. Sedari kecil hingga dewasa AL dan DI tinggal terpisah. AL pun hanya melihat sosok ayah dan ibunya dari foto yang masih tersimpan.

AL tinggal di asrama putri bersama dengan teman-temannya dan sudah memasuki tahun keempat. Berbagai kegiatan di asrama di asrama dan sekolah diikuti karena merupakan peraturan dari asrama, namun dikarenakan saat ini sedang mempersiapkan ujian nasional, AL hanya diminta untuk belajar dan tidak lagi mengikuti kegiatan di sekolah. Proses belajarnya dilakukan di asrama atau di luar jam sekolah bersama dengan temantemannya.

d. Informan NI

Informan NI merupakan anak kedua dari pasangan OD dan RI yang lahir di Kota Garut. NI berusia 16 tahun dan sedang menempuh pendidikan di kelas 10 sekolah menengah atas di bawah naungan Yayasan Esa Nugraha. NI menjalankan kegiatan rutin pendidikan dengan bersekolah setiap hari Senin hingga Sabtu layaknya sekolah reguler pada umumnya. Setelah mengikuti kegiatan sekolah, NI kembali ke asrama untuk mengikuti kegiatan di asrama seperti teman-temannya yang lain.

Sebelum tinggal di asrama NI tinggal bersama dengan bibinya di Garut. Semenjak kecil NI tinggal bersama dengan bibinya dan terpisah dengan ayah dan ibunya, hal itu dilakukan karena bibinya hanya tinggal seorang diri. Tujuannya adalah NI dapat menemani bibinya yang tinggal sendiri. Selain itu rumah bibi dan ayah ibunya masih dalam satu desa yang sama sehingga memungkinkan untuk berkomunikasi.

NI tinggal di asrama putri bersama dengan teman-temannya dan sudah berjalan 
7 bulan. Berbagai kegiatan di asrama di asrama dan sekolah diikuti karena merupakan peraturan dari asrama. Keluarganya yang merujuk NI ke asrama setelah ayahnya sudah meninggal dunia. Ketika dirujuk ke asrama, keluarganya juga ikut mengantar dan telah memenuhi persyaratan tinggal di asrama. Setelah tinggal di asrama ia tempatkan ke asrama putri yang telah ditetapkan oleh pengurus yayasan Esa Nugraha.

e. Informan FN

Informan FN merupakan anak kedua dari pasangan DN dan HN yang lahir di Kota Bandung. FN berusia 17 tahun dan sedang menempuh pendidikan di kelas 11 sekolah menengah atas dibawah naungan Yayasan Esa Nugraha. Sama seperti anak asuh lainnya, setiap hari FN menjalankan rutinitas belajarnya di sekolah dari hari Seninhingga Sabtu. Setelah mengikuti kegiatan di sekolah FN kembali ke asrama putra tempat ia tinggal.

Sebelum tinggal di asrama $\mathrm{FN}$ tinggal bersama dengan kakak dan neneknya di Citepus. Kakaknya bekerja di salah satu swalayan di Bandung sedangkan neneknya berjualan di rumah. Setiap hari pemenuhan kebutuhan FN ditanggung oleh nenek dan kakaknya, hal itu dikarenakan kedua orang tua FN telah meninggal dunia.

Perujukan ke asrama dilakukan ketika FN duduk di bangku kelas 10 sekolah menengah akhir. FN dirujuk ke asrama oleh keluarganya melalui perwakilan kakak kandung dari FN. Perujukan dilakukan ketika ayah dan ibu FN telah meninggal dunia. Pada saat wawancara FN sudah terhitung berjalan 7 bulan tinggal di asrama setelah proses perujukan.

\section{f. Informan CA}

CA merupakan anak ketiga dari pasangan SA dan RA yang lahir di Kota Bandung. CA berusia 16 tahun dan sedang menempuh pendidikan di kelas 10 sekolah menengah atas yang berada dalam naungan
Yayasan Esa Nugraha. Layaknya temanteman yang lain, CA menjalankan aktivitas sehari-hari dengan bersekolah dari hari Senin hingga Sabtu. Setelah melaksanakan kegiatan di sekolah, CA juga kembali melakukan kegiatan di asrama dan di luar asrama bersama dengan teman-temannya.

Sebelum tinggal di asrama, CA tinggal bersama dengan ayah dan ibunya di daerah Soreang. Ayahnya bekerja sebagai petani dan mengurus peternakan. Sedangkan ibunya pernah bekerja namun sudah tidak lagi dikarenakan riwayat penyakit darah tinggi. Pada saat kelas 9 sekolah menengah pertama, ibunya meninggal dunia. Kondisi tersebut membuat salah satu pengurus yayasan menawarkan CA untuk tinggal di asrama.

Perujukan ke asrama dilakukan ketika CA duduk di bangku kelas 10 sekolah menengah akhir. CA dirujuk ke asrama oleh keluarganya melalui perantara ketua LKSA setelah ibunya meninggal dunia. Pada saat ibunya meninggal CA direkomendasikan oleh gurunya untuk tinggal di asrama. Setelah mempertimbangkan hal tersebut akhirnya CA dirujuk ke asrama dan sudah tinggal di asrama berjalan 7 bulan.

\section{Latar Belakang Kehilangan Orang Tua yang Dialami Anak}

Berdasarkan penelitian yang telah dilakukan, terdapat konstelasi sebab dan akibat kehilangan orang tua yang dialami oleh anak. Pertama, meninggalnya orang tua memberikan kesan mendadak bagi anak. Kesan tersebut dirasakan karena anak merasa orang tuanya dalam keadaan baikbaik saja sehingga pada saat proses meninggalnya orang tua, anak merasa tidak dapat melakukan pertolongan.

Kedua, anak memiliki respon menyalahkan diri akibat meninggalnya 
orang tua. Perasaan itu disebabkan karena anak memiliki perasaan tidak dapat memiliki kesempatan untuk bersama orang tuanya lagi. Kesempatan tinggal bersama keluarga juga hilang karena setelah meninggalnya orang tua, anak dirujuk ke LKSA oleh keluarganya.

Ketiga, setelah meninggalnya orang tua, anak tidak memiliki hubungan yang dekat dengan keluarganya yang lain. Kondisi itu ditunjukkan karena keluarga tidak memiliki jadwal rutin dalam mengunjungi anak di asrama. Anak juga tidak memiliki waktu khusus untuk menghubungi keluarga lainnya melalui telepon atau media online lainnya.

Keempat, selama tinggal di LKSA anak juga merasakan pengalaman kehilangan orang tua adalah pengalaman yang mengganggu aktivitasnya. Gangguan yang dialami anak terjadi baik pada tataran fisik, emosi, maupun kognisi.

\section{Strategi Berpusat pada Masalah Anak} yang Memiliki Pengalaman Kehilangan Orang Tua

Hasil penelitian yang berkaitan dengan strategi berpusat pada masalah yang dilakukan oleh anak berkaitan dengan kemampuan anak dalam memandang permasalahan yang dialami melalui beberapa upaya yang dilakukan.

Pertama, upaya yang dilakukan anak dalam mencari dukungan orang lain dilakukan melalui pengungkapan kondisi kehilangan orang tua kepada pengasuh. Pengungkapan tersebut belum dilakukan atas dasar inisiatif anak karena kendala yang dihadapi anak seperti perasaan malu pada anak. Selain itu belum adanya media kelompok untuk melaksanakan konseling pada anak khususnya yang memiliki pengalaman kehilangan orang tua. Pada kondisi tertentu anak membutuhkan pandangan mengenai hal-hal yang dilakukan dalam menghadapi kondisi kehilangan orang tua yang dialami ketika berada di LKSA.
Kedua, upaya konfrontasi yang dilakukan oleh anak dilakukan melalui perilaku agresif secara verbal. Perilaku tersebut dilakukan ketika anak dihadapkan pada perasaan kehilangan yang muncul namun belum didukung oleh lingkungan pertemanannya. Akibatnya anak juga memiliki perselisihan dengan teman sebayanya yang dipengaruhi perasaan kehilangan yang sedang dialaminya.

Upaya konfrontasi anak tidak berkembang menjadi tindakan agresif fisik atau tindakan yang membahayakan anak dan anak lainnya. Anak tidak memiliki kecenderungan untuk melanggar peraturan melalui tindakan konfrontasi yang dilakukannya karena terdapatnya peraturan di LKSA serta keberadaan pengasuh yang meminimalisir perselisihan yang terjadi.

Ketiga, berkaitan dengan upaya anak dalam mengatasi kondisi kehilangan orang tua yang dirasakan ketika berada di LKSA. Anak dapat mengetahui penyebab kondisi kehilangan orang tua muncul dan mengganggunya dalam menjalankan aktivitas lainnya. Kondisi itu dirasakan anak ketika sedang dalam keadaan sendiri serta merasa kesepian. Perasaan tersebut semakin menguat ketika waktu malam hari dan mengganggu anak untuk tidur.

Keberadaan orang tua anak asuh lain di LKSA maupun di sekolah juga menjadi pemicu anak merasakan kehilangan orang tua. Selain interaksi anak lain dengan orang tuanya secara langsung, komunikasi anak asuh lain dengan keluarganya melalui media online juga menjadi pemicu kondisi kehilangan orang tua pada anak.

Kondisi kehilangan orang tua yang muncul melalui pemicu tersebut dihadapi anak melalui penyelesaian tertentu. Upaya itu dilakukan dengan cara beribadah. 
Langkah itu dipilih karena disesuaikan dengan kemampuan anak dalam menjangkau penyelesaian serta pendekatan keagamaan yang ada di LKSA.

\section{Strategi Berpusat Pada Emosi Anak yang Memiliki Pengalaman Kehilangan Orang Tua}

Hasil penelitian yang terkait dengan strategi berpusat pada emosi anak berkaitan dengan kemampuan anak dalam menghadapi kondisi kehilangan dengan pengelolaan emosi. Pertama, upaya pengabaian kondisi kehilangan orang tua dilakukan anak melalui beberapa cara. Gawai menjadi media dalam mengabaikan kondisi kehilangan oleh anak. Perilaku tersebut dilakukan anak melalui penggunaan media sosial ataupun permainan yang ada. Rata-rata penggunaan gawai anak dalam kondisi tersebut adalah 20 menit hingga 1 jam. Selain menggunakan media, anak juga melakukan self-talk dengan cara meyakinkan diri untuk mengabaikan kondisi kehilangan yang dialaminya. Upaya itu dilakukan ketika anak tidak memiliki kesempatan dalam menggunakan gawainya.

Kedua, anak melakukan upaya kontrol diri dalam menghadapi kondisi kehilangan orang tua ketika berada di LKSA. Upaya kontrol diri anak dilakukan melalui pengendalian emosi dengan pendekatan keagamaan yakni berzikir. Tindakan itu dilakukan anak dengan menghindari situasi atau aktivitas yang ada di LKSA dan memilih kamar atau masjid sebagai tempat menyendiri.

Perilaku lain juga dikemukakan oleh anak dengan memendam emosi kehilangan orang tua yang dialaminya. Tindakan itu dilakukan karena anak belum merasa yakin untuk mengungkapkan kondisinya kepada teman sebaya. Anak tidak ingin mendapatkan stigma negatif apabila anak menceritakan kondisinya kepada teman sebayanya.
Anak juga menyatakan melakukan pengungkapan emosi secara tidak terkendali dengan menangis atau melakukan tindakan merusak barangbarang yang dimiliki. Kondisi itu dilakukan ketika perasaan kehilangan orang tua yang dialami muncul dan keterbatasan akses untuk mengunjungi keluarganya yang ada di kampung halaman.

Ketiga, dalam menghadapi kondisi kehilangan orang tua yang dialami, anak masih memiliki perasaan bertanggung jawab dalam menghadapi kehidupan selanjutnya. Upaya itu didasarkan pada pemikiran dan pengalaman anak dalam menyelesaikan sesuatu tanpa keterlibatan orang tua seperti menentukan rencana karier di masa depan. Dalam pelaksanaan tanggung jawab atas kondisi kehilangan yang dialami, anak masih memiliki kendala. Kendala tersebut berkaitan dengan ruang lingkup pembelajaran. Anak belum memiliki komitmen khusus dalam menentukan target pembelajaran.

Kendala yang lainnya adalah terganggunya kepercayaan diri anak dalam melakukan tanggung jawab tanpa kehadiran orang tua. Gangguan tersebut muncul karena anak memiliki pemikiran terbatasnya sumber daya dan dukungan terhadap kehidupannya setelah lulus dari LKSA. Sumber daya dan dukungan tersebut berkaitan dengan minimnya kondisi ekonomi anak serta dukungan emosional keluarga terhadap pelaksanaan tanggung jawab anak.

Keempat, berkaitan dengan upaya penghindaran anak terhadap kondisi kehilangan orang tua yang dialami ketika berada di LKSA. Anak masih memiliki perasaan menolak atas kehilangan orang tua yang dialami. Penolakan tersebut terjadi 
ketika anak membutuhkan figur orang tua dalam menyelesaikan permasalahan yang dialami baik sebagai siswa di sekolah maupun anak asuh di LKSA.

Kondisi itu mengakibatkan anak melakukan tindakan untuk menghindari kondisi tersebut. Tindakan tersebut dilakukan anak dengan menggunakan gawai diluar batas pemakaian yang ditentukan, misalnya menggunakan gawai hingga larut malam dan mengganggu waktu tidurnya. Tindakan tersebut juga mengakibatkan terganggunya waktu ibadah anak.

Selain itu anak juga memilih beristirahat atau tidur dalam menghindari kondisi kehilangan orang tua yang dialami dan berharap dapat bertemu dengan orang tuanya di dalam mimpi. Waktu tidur anak juga lebih banyak dibandingkan dengan teman-teman yang lain karena anak menggunakan waktu bermain atau belajar untuk waktu tidurnya.

Kelima, berkaitan dengan upaya anak dalam memaknai pengalaman kehilangan orang tua. Anak memiliki pandangan terhadap keberhargaan dirinya pasca meninggalnya orang tua. Pandangan tersebut berkaitan dengan keberadaan dirinya di dalam lingkungan pertemanan, selaras dengan interaksinya dengan anak-anak lain yang masih memiliki orang tua. Hasil penelitian menunjukkan anak masih memiliki perasaan rendah diri dari anak lain yang masih memiliki orang tua.

Perasaan tersebut disebabkan karena anak beranggapan anak-anak lain yang masih memiliki orang tua dapat memberikan dukungan yang lebih untuk keberlangsungan kehidupan anak baik secara ekonomi maupun emosional. Disamping itu anak juga memiliki anggapan bahwa orang tua adalah sumber dukungan utama kehidupan anak yang saat ini sudah tidak bisa dimiliki lagi.

\section{PEMBAHASAN}

Pembahasan dalam penelitian ini disesuaikan dengan fakta-fakta hasil penelitian di lapangan serta tujuan penelitian yakni mendeskripsikan latar belakang kehilangan orang tua yang dialami anak, serta strategi koping anak yang terdiri dari strategi berpusat pada masalah dan strategi berpusat pada emosi berdasarkan hasil penelitian yang ditemukan. Adapun pembahasan penelitian dapat dijabarkan sebagai berikut:

\section{Latar Belakang Kehilangan Orang Tua yang Dialami Anak \\ Hasil penelitian menunjukkan bahwa} kematian orang tua memberi kesan mendadak bagi anak. Kondisi itu mengakibatkan anak mengalami gangguan baik pada tataran kognitif maupun emosi dalam menjalankan kehidupan di LKSA dan tidak tinggal bersama keluarga. Kondisi tersebut selaras dengan pendapat yang dikemukakan oleh McClatchey \& Wimmer (2014) yang mengemukakan bahwa pengalaman kematian orang tua secara tibatiba atau tidak diharapkan merupakan pengalaman traumatis yang dapat mengganggu emosi dan perilaku seseorang.

Perasaan sedih dan kehilangan juga dirasakan karena anak tidak dapat bertemu orang tuanya lagi. Perasaan tersebut kembali muncul ketika anak harus berada di LKSA. Jarak yang jauh dan kondisi yang merangsang kembali ingatan anak terhadap pengalaman kehilangan orang tua juga semakin dirasakan sehingga mengakibatkan duka bagi anak.

Hasil penelitian tersebut juga selaras dengan pendapat yang dikemukakan oleh Bowbly (dalam Winta \& Syafitri, 2019) yang mengemukakan bahwa fase berduka adalah serangkaian waktu dimana 
seseorang merasakan kesedihan dan hilang pengharapan. Meskipun orang tersebut telah menerima peristiwa kehilangan secara emosional, namun hidup tanpa orang yang dicintai tidak dapat dilalui dengan mudah.

Disisi lain anak masih memiliki anggota keluarga tetapi anak tidak tinggal bersama melainkan tinggal di LKSA yang jaraknya relatif jauh dari keluarga. Aksesibilitas lokasi keluarga yang tidak dapat dijangkau membuat anak merasakan dampak kehilangan orang tua dalam kondisi tidak dengan keluarganya. Padahal dalam kondisi ini keluarga dibutuhkan untuk memberikan dukungan secara emosional.

Fakta penelitian tersebut selaras dengan pendapat yang dikemukakan oleh Crunk et al., (2017) yang mengemukakan bahwa kehilangan membuat seseorang ingin lebih dekat dengan orang yang dicintai. Selain orang tua, keluarga juga menjadi unit sosial yang dibutuhkan anak dalam melanjutkan kehidupan pasca meninggalnya orang tua. Namun hal tersebut tidak dapat dirasakan secara langsung karena anak tidak tinggal bersama dengan keluarga.

Selain itu hasil penelitian juga menunjukkan anak merasakan gangguan atas pengalaman kehilangan orang tua ketika berada di asrama. Gangguan itu juga diperkuat ketika anak tidak tinggal bersama dengan keluarga melainkan harus tinggal di LKSA. Fakta tersebut sesuai dengan pendapat yang dikemukakan oleh Garos, (2020) yang mengemukakan bahwa kehilangan mengakibatkan perasaan sakit dan khawatir terkait kondisi yang sebenarnya tidak akan terjadi. Kekhawatiran tersebut menjadi faktor yang mempengaruhi terganggunya anak dalam menjalankan kehidupannya.

\section{Strategi Berpusat Pada Masalah Anak yang Memiliki Pengalaman Kehilangan Orang Tua}

Pembahasan pertama berkaitan dengan upaya anak dalam mencari dukungan orang lain. Hasil penelitian menunjukkan bahwa anak belum memiliki inisiatif dalam mengungkapkan gangguan atas kondisi kehilangan orang tua secara langsung kepada pengasuh. Kondisi tersebut selaras dengan pendapat yang dikemukakan oleh Melinda et al., (2019) yang mengemukakan bahwa hambatan yang dialami anak dalam mencari dukungan untuk mengungkapkan permasalahan kehilangan orang tua yang dialami berkaitan dengan perasaan takut dalam mengungkapkan permasalahan sehingga anak cenderung menarik diri dari lingkungan.

Walaupun belum memiliki inisiatif, anak bersedia jika diminta untuk mengungkapkan kondisi kehilangan atau duka yang sedang dialaminya, namun perlu disediakan media pertemuan khusus. Hal tersebut selaras dengan dikemukakan oleh Lazarus dan Folkman (1984) yang mengemukakan bahwa manusia memerlukan lingkungan dalam rangka memecahkan permasalahan yang dialami.

Kedua, berkaitan dengan upaya konfrontasi yang dilakukan oleh anak. Hasil penelitian menunjukkan bahwa anak menunjukkan perilaku agresif ketika lingkungan pertemanan yang dianggap mengganggu anak ketika perasaan duka atau kehilangan kehilangan orang tua muncul. Perilaku agresif ditunjukkan melalui kata-kata atau verbal.

Fakta mengenai perilaku anak tersebut tersebut selaras dengan pendapat Maryam (2017) yang mengemukakan 
bahwa konfrontasi dapat dilakukan dengan menunjukkan perilaku agresif serta bertentangan terhadap peraturan yang berlaku. Namun anak cenderung untuk melakukan perilaku agresif secara fisik karena terdapat aturan lembaga dan keberadaan pengasuh.

Perilaku yang dipilih anak sesuai dengan pandangan Abdelaziz et al., (2013) mengemukakan bahwa dalam kondisi tertentu konfrontasi dapat diminimalisir ketika terdapat pengasuh yang mampu memediasikan antara stres dengan strategi koping yang digunakan oleh anak. Ketika berada di asrama, anak terikat dengan peraturan dan terdapat pengasuh yang mengawasi tindakan anak secara umum.

Ketiga berkaitan dengan upaya anak dalam mengatasi kondisi kehilangan orang tua yang dirasakan ketika berada di LKSA. Hasil penelitian menunjukkan sendiri adalah kondisi anak merasakan gangguan atas pengalaman kehilangan orang tua. Kondisi tersebutlah yang dianalisis anak sebagai situasi yang menimbulkan permasalahan kehilangan orang tua. Pernyataan tersebut selaras dengan pendapat yang dikemukakan oleh (McClatchey \& Wimmer (2014) yang mengemukakan bahwa sendiri dan kesulitan untuk melupakan adalah dampak kehilangan orang tua yang dapat dialami seseorang.

Dalam menghadapi kondisi tersebut anak mencari solusi atas permasalahan tersebut. Upaya yang dilakukan anak adalah dengan cara beribadah. Ibadah yang dikerjakan anak dapat berupa solat, membaca Al-Qur'an, dan berdoa. Rangkaian aktivitas tersebut dilakukan sesuai dengan kapasitas anak serta diperkuat dengan pendekatan keagamaan yang digunakan di LKSA. Hal ini selaras dengan pendapat yang dikemukakan oleh Krisnani \& Farakhiyah (2017) yang mengemukakan bahwa pengambilan keputusan dapat dikatakan berhasil jika individu dapat mampu melibatkan kemampuan yang dimiliki.

\section{Strategi Berpusat Pada Emosi Anak yang Memiliki Pengalaman Kehilangan Orang Tua}

Pembahasan pertama berkaitan dengan upaya anak dalam pengabaian atas kondisi kehilangan orang tua yang dialami. Hasil penelitian menunjukkan bahwa gawai adalah salah satu media yang digunakan untuk mengabaikan gangguan atas pengalaman kehilangan orang tua, hal tersebut selaras dengan yang dikemukakan oleh Lazarus dan Folkman (1984) yang mengemukakan bahwa dalam melakukan pengabaian seseorang berkeinginan untuk mencoba melupakan permasalahannya. Selain itu bentuk pengalihan yang dilakukan anak juga selaras dengan pendapat Hube (dalam Diana, 2015) yang menunjukkan bahwa seseorang dapat melakukan bentuk pengalihan dengan cara katarsis melalui aktivitas tertentu yang mengurangi emosi.

Selain itu anak juga melakukan selftalk ketika merasakan duka kehilangan orang tua. Anak juga mengungkapkan tujuan mereka melakukan self-talk yakni untuk menguatkan diri dan mencoba melupakan duka yang muncul. Hal tersebut selaras dengan pendapat yang dikemukakan oleh Ahmad \& Halinda (2019) yang mengemukakan bahwa seseorang dapat melakukan self-talk dengan berkata pada diri sendiri baik positif maupun negatif dengan mengaitkan sesuatu dengan individu sebagai wujud mekanisme koping.

Kedua, berkaitan dengan upaya anak dalam melakukan kontrol diri. Hasil penelitian menunjukkan bahwa anak memilih menyendiri ketika kondisi duka 
muncul dan melakukan kegiatan berzikir. Pilihan anak tersebut selaras dengan pendapat yang dikemukakan oleh Aviyah \& Farid (2014) yang mengemukakan bahwa terdapat hubungan antara kontrol diri dengan perilaku religiusitas yang dilakukan oleh anak.

Selain itu anak juga memilih memendam emosinya ketika merasakan duka kehilangan orang tua. Upaya memendam emosi anak dilakukan dengan cara menarik diri atau melakukan tindakan merusak barang-barang yang dimiliki. Hasil penelitian tersebut selaras dengan pendapat Gina et al., (2020) yang mengemukakan bahwa kontrol diri dan agresivitas pada remaja berbanding terbalik, yakni apabila kontrol diri maka agresivitas rendah dan begitu pula sebaliknya.

Ketiga, berkaitan dengan upaya penerimaan tanggung jawab anak atas kondisi kehilangan orang tua yang dialami. Hasil penelitian menunjukkan bahwa anak memiliki rasa tanggung jawab dalam menjalakan kehidupan selanjutnya setelah meninggalnya orang tua.

Upaya pelaksanaan tanggung jawab tersebut belum dirasakan secara maksimal oleh anak khususnya dalam bidang pendidikan. Anak menunjukkan belum memiliki perencanaan pendidikan yang pasti karena merasa tidak adanya dukungan dari keluarga. Perencanaan yang tidak pasti akan keberlanjutan pendidikan selaras dengan pendapat yang dikemukakan oleh Azmi (2015) yang mengemukakan bahwa emosi menghambat konsentrasi belajar individu dan ditampilkan dengan semangat yang melemah karena merasakan kekecewaan.

Hal tersebut juga diperkuat oleh pernyataan Makhmudah (2018) yang mengemukakan bahwa salah satu hambatan anak dalam menentukan keberlanjutan pendidikan adalah faktor eksternal yakni dukungan sosial keluarga.

Keempat, berkaitan dengan upaya untuk menghindari kondisi kehilangan orang tua yang dilakukan oleh anak. Hasil penelitian menunjukkan anak masih memiliki penolakan atas meninggalnya orang tua. Penolakan yang terjadi pada anak selaras dengan pendapat yang dikemukakan oleh Smith (dalam Santoso et al., 2018) yang menyatakan bahwa seseorang dapat melakukan penolakan dengan reaksi emosi terhadap situasi kehilangan yang dialami.

Upaya menghindari rasa duka juga dilakukan anak dengan bermain gawai atau tidur di waktu yang tidak seharusnya. Perilaku tersebut selaras dengan pendapat yang dikemukakan oleh Andrianto (2019) yang menyatakan bahwa anak dapat melakukan perilaku negatif ketika kurang mendapatkan perhatian dan tuntunan dari orang tua. Dalam hal ini anak menggunakan gawai dengan batas pemakaian yang tidak sesuai dengan aturan di LKSA.

Kelima, berkaitan dengan upaya pemaknaan anak terhadap kondisi kehilangan orang tua. Hasil penelitian menunjukkan bahwa anak memiliki perasaan rendah diri jika dibandingkan dengan anak-anak lain yang masih memiliki orang tua. Namun disisi lain anak memiliki pandangan terkait dengan kemungkinan yang dihadapi tanpa adanya keberadaan orang tua. Kondisi tersebut selaras dengan pendapat yang dikemukakan oleh Shiota \& Levenson (2012) bahwa terdapat peran penilaian kognitif pada seseorang dalam mendorong kualitas pengalaman emosional selaras dengan pemaknaan kehilangan yang dimilikinya. 


\section{KESIMPULAN}

Berdasarkan hasil penelitian dapat disimpulkan bahwa terdapat strategi koping yang dilakukan anak dalam merespon pengalaman kehilangan orang tua. Strategi tersebut relatif sama antara anak asuh satu dengan yang lainnya, baik yang dilakukan oleh informan SA, SI, AL, NI, FN, maupun CA. Hal tersebut dikarenakan dalam penelitian ini anak tidak menunjukkan perbedaan yang terlalu besar dalam upaya pelaksanaan strategi koping. Sesuai dengan karakteristik, anak juga tidak memiliki perbedaan usia yang jauh. Hal ini membuat anak berada dalam tahapan perkembangan yang sama, sehingga strategi koping yang dilakukan juga berdasarkan tahapan perkembangan anak yang sedang dilaluinya.

Keberadaan anak dalam ruang lingkup yang sama juga menjadi faktor penentu keseragaman strategi koping yang dilakukan oleh informan SA, SI, AL, NI, FN, dan CA. Perbedaaan jenis kelamin juga tidak memberikan perbedaan yang signifikan dalam penggunaan strategi koping. Dalam hal ini, peraturan asrama menjadi media yang bertujuan untuk mencegah anak dalam menggunakan strategi koping yang bersifat negatif. Anak memiliki keterikatan yang kuat terhadap peraturan karena minimnya data jumlah pelanggaran yang dilakukan oleh anak ketika berada di asrama.

Informan anak baik SA, SI, NI, AL, FN, maupun $\mathrm{CA}$ juga telah menggunakan strategi berfokus pada masalah dan strategi berpusat pada emosi dalam mengatasi duka kehilangan orang tua ketika berada di asrama. Upaya tersebut dapat dikatakan sebagai salah satu langkah tepat karena penggunaan kedua jenis koping dapat mengoptimalkan respon anak baik secara kognisi maupun emosi dalam mengatasi duka kehilangan yang dialami.
Duka kehilangan orang tua yang dialami anak dapat ditransformasikan dengan perilaku positif apabila penggunaan kedua jenis koping dioptimalkan. Upaya itu dilakukan agar anak dapat memahami pengalaman kehilangan orang tua serta mengendalikan emosi yang dimilikinya secara bersamaan. Pada kondisi ini, pengasuh memiliki andil dalam mendukung penggunaan strategi koping positif yang dilakukan oleh anak. Pengasuh memberikan dukungan secara emosional kepada anak dalam merespon perasaan duka yang dialami.

Walaupun anak telah menggunakan kedua jenis strategi koping, namun masih terdapat beberapa kendala dalam pelaksanaannya. Kendala tersebut berkaitan dengan keterbatasan waktu dan jumlah pengasuh pada anak, sehingga diperlukan upaya pemberdayaan yang dilakukan pada anak. Anak perlu mendapatkan pelayanan melalui fasilitasi kelompok yang dapat membantu mengatasi duka kehilangan yang dialami. Kelompok tersebut juga beranggotakan anak-anak yang memiliki pengalaman kehilangan orang tua. Oleh karena itu, peneliti merekomendasikan bahwa media kelompok bantu diri dapat menjadi treatment bagi anak.

Treatment tersebut bertujuan untuk meningkatkan strategi koping anak yang memiliki pengalaman kehilangan orang tua di LKSA Nugraha Kota Bandung melalui media kelompok. Harapannya kelompok tersebut dapat berdaya dalam merespon perasaan duka kehilangan yang dialami anak secara berkelanjutan karena melibatkan anak asuh yang memiliki pengalaman serupa secara partisipatif. 


\section{DAFTAR PUSTAKA}

Abdelaziz, T., Abdulla, T., \& Vostanis, P. (2013). Coping Strategies of Children And Adolescents Exposed to War Conflict. Arabpsynet E.Journal, 39(40).

Ahmad Yusuf, H. (2019). Implementasi Teknik Self Talk Untuk Meningkatkan Aktivitas Belajar Siswa Di Smp Negeri 1 Pangkep. Jurnal Ilmu Pendidikan Dasar, 2(1), 326330.

Andrianto. (2019). Faktor- Faktor Penyebab Kenakalan Remaja di Lebak Mulyo Kecamatan Kemuning Kota Palembang. Jurnal PAI Raden Patah V 1(1), 82-104.

Aviyah, E., \& Farid, M. (2014). Religiusitas, Kontrol Diri dan Kenakalan Remaja. Persona:Jurnal Psikologi Indonesia. 3(02), 126-129.

Azmi, N. (2015). Potensi Emosi Remaja dan Perkembangannya. 2(1), 36-46.

Creswell, J. W. (2014). Research Design: Qualitative, Quantitative, and Mixed Method Approaches. California: SAGE Publications.

Crunk, A. E., Burke, L. A., Neimeyer, R. A., Robinson, E. H. M., \& Bai, H. The Coping Assessment for Bereavement and Loss Experiences (CABLE): Development and initial validation. (2017. ) Dissertation. University of Central Florida.

Diana, R. R. (2015). Pengendalian Emosi Menurut Psikologi Islam. Unisia, 37(82), 41-47.

Garos, S. (2020). Goodbye is Just the Beginning. Journal of Loss and Trauma. 26(3), 1-6.

Gina Ayu Nilamsari, Gian Sugiana Sugara, D. S. (2020). Analisis Determinasi Diri Remaja. Journal of Innovative Counseling : Theory, Practice \& Research. 4(1), 20-33.

Kementerian Sosial. (2019). Rehsos Anak Gelar Rakernas Forum LKSA-PSAA Tahun 2019. Diakses dari https://kemensos.go.id/rehsos-anakgelar rakernas-forum-lksa-psaa-tahun2019 pada 27 Februari 2021

Krisnani, H., \& Farakhiyah, R. (2017). Meningkatkan Kemampuan Pengambilan Keputusan Reality Therapy. Share Social Work. 7(2), 1-79.
Makhmudah, S. (2018). Penguatan Peran Keluarga Dalam Pendidikan Anak. Martabat. Jurnal Perempuan Dan Anak. 2(2).

Maryam, S. (2017). Strategi Coping: Teori Dan Sumber Dayanya. JURKAM: Jurnal Konseling Andi Matappa. 1(2).

McClatchey, I. S., \& Wimmer, J. S. (2014). Coping with Parental death as Seen From The Perspective of Children Who Attended A Grief Camp. Qualitative Social Work Journal. 13(2), 221-236.

McGuire, S. L., McCarthy, L. S., \& Modrcin, M. A. (2013). An ongoing concern: Helping children comprehend death. Open Journal of Nursing. 3(3), 307-313.

Melinda et al. (2019). Coping with Grief and Loss. Diakses dari https://www.helpguide.org/articles/grief/ c oping-with-grief-and-loss.htm pada 27 Februari 2021.

Miles, Huberman, \& Saldana. (2014). Qualitative Data Analysis (A Methods Sourcebook) third edition. California: SAGE Publications.

Mitchell, L. A., \& Murillo, J. F. (2016). Social Work Students 'Preparedness for Grief and Loss Services. Thesis. California State University.

Petr. 2004. Social Work with Children and Their Families. New York: Oxford University Press.

Salscheider, K. (2016). Grieving Students : School Social Workers 'Perspectives. Clinical Social Work Research Paper. ST Catherine University.

Santoso, M. B., Wibhawa, B., \& Ishartono, I. (2018). Penerimaan Orang Tua Terhadap Anak Dengan Retardasi Mental. Share: Social Work Journal, 8(1), 31.

Schofield, G., Moldestad, B., Höjer, I., Ward, E., Skilbred, D., Young, J., \& Havik, T. (2011). Managing Loss and A Threatened Identity: Experiences of Parents of Children Growing up in Foster Care, The Perspectives Of Their Social Workers and Implications for Practice. British Journal of Social Work, 
41(1), 74-92.

Shiota, M. N., \& Levenson, R. W. (2012). Turn Down The Volume or Change The Channel? Emotional Effects of Detached Versus Positive Reappraisal. Journal of Personality and Social Psychology. 103(3), 416-429.

Sri Hardiyanti, Diah Karmiyati, D. S. H. (2017). Parenting Self Efficacy Ayah Pada Nuclear dan Extended Family. Jurnal Ilmiah Psikologi Terapan. 37(3), 193-203.

Telaumbanua, M. M., \& Nugraheni, M. (2018). Faktor yang Mempengaruhi Upaya Ibu Rumah Tangga dalam Meningkatkan Kesejahteraan Sosial. Jurnal PKS. 17(3), 217-226.

Winta, M. V. I., \& Syafitri, A. K. (2019). Coping Stress Pada Ibu Yang Mengalami Kematian Anak. Philanthropy: Journal of Psychology. 3(1), 14.

Wong, F. K. C. (2013). Helping a Child Cope with Loss by Using Grief Therapy. Discovery - SS Student E-Journal. 2, 195215.

Zastrow. 2015. Social Work with Groups: A Comprehensive Worktext. USA: Cengage Learning. 